\title{
Gender and Sexuality
}

Together with deep ecology and bio-regionalism, eco-feminism is considered one of the strands of the ecology movement with the most prominent spiritual elements. Closely connected with feminist or women-centered varieties of Neopaganism, eco-feminism takes women's alleged proximity to nature and its cycles as its logical basis. The hope is that a spiritual approach of cooperation between (wo)man and nature will replace dominance and exploitation. Traditionally, alternative religions and spiritual movements, especially theosophy (which inspired many strands of Neopaganism), have provided opportunities for women to rise into influential positions. The opposite is the case for Germanic Faith in the early 2oth century, as well as for contemporary Asatru. Whereas the former shared the outspoken masculinism of the völkisch movement and centered on warrior heroism, the latter, especially the North American Asatru revival in the 1970s, was initially borne out of an enthusiasm for the figure of the Viking, the male warrior, adventurer, and conqueror, and his war-gods Thor, Odin, and Tyr. Imagery of male physical power and violence still forms the external perception of Asatru and is reflected in the gender ratio of most groups, most commonly $60-70 \%$ men. ${ }^{1}$ Nevertheless, women have been active in Germanic Neopaganism all along. By forging links to other, more women-centered varieties of earth and goddess spirituality and Neopaganism, such as Wicca, which puts an emphasis on female deities and priestesses, they have contributed to popular images of Asatru and its gods and goddesses.

As we have seen in the previous chapter, disillusionment with a destructive attitude toward the natural environment and human nature alike is a strong motivation to turn away from mainstream Christianity and search for alternative religious models. Women, femininity, corporeality, and sexuality have traditionally been equated with nature. Thus, another strong motive for the alienation from established religion is the desire to revalue these factors and search for arenas of equality, permission, and experimentation with regard to gender and sexuality in alternative spiritual movements. This search has been one of the driving forces in modern Western occultism and Neopaganism. Like ecologism, the related movements - feminism, libertarianism, and the queer movement - have a reputation for belonging to the political left. And just

1 Bifrost in Norway as well as the very small Nornirs Ætt in German and NTF in Denmark being significant exceptions with around $50 \%$ women amongst the members.

(C) KONINKLIJKE BRILL NV, LEIDEN, 2016 | DOI 10.1163/9789004309517_009

This is an open-access article distributed under the terms of the Creative Commons Attribution-

NonCommercial 3.o. Unported (CC BY-NC 3.o) License, http://creativeccommons.org/licenses/by-nc/3y9/89004309517 
as with ecologism, this is one factor that has made women's spirituality and sexual experimentation an ambivalent issue for Germanic Neopaganism. Professing to spiritual equality between men and women, which allegedly is deeply rooted in the Germanic tradition, and to a freer attitude towards body and sexuality, helps Asatruers align themselves with accepted new social movements and thus gain respectability. At the same time, Asatru remains fairly conservative with regard to questions of gender, family, and sexuality, and tends to view forays into such alternative ideologies with great suspicion. But, as is the case with green spirituality, the picture is rather more complex than such ostensibly easy delineations may suggest. On the one hand, feminism, especially in its theological and spiritual varieties, has at times recalled conservative models of gender and sexuality, combining them with racist traditions. The same applies to parts of the queer movement today, just as it did for the sexual liberation and libertarian movements aligned with occultism around 1900.

Such ambivalences, and the significance of gendered images within Asatru and their partly contradictory nature, are reason enough to further investigate concepts of masculinity, femininity, and sexuality within Heathenism, as well as their transformations and alliances with other religious, social, and intellectual currents. Gender identity and sexualities have been contested fields in modernity, particularly in the new religious movements that appeared around 190o. In spite of its relative gender conservatism, Asatru has taken up a plethora of ideas from alternative movements on gender and sex, while forming conceptions of the 'Germanic,' which again entered into broader gender movements. It can therefore serve as a small and manageable field in which to study interdependencies between gender, sexuality, religion, race, ethnicity and nationality. It allows us to question the image of an absolutely masculinist or conservative family-oriented Heathenism and describe it as a field of tension between contradictory and competing concepts of gender and sexuality. Even more so, however, it will allow us to uncover some politically ambiguous strands within alternative movements and theories: feminism, the men's movement, and masculinity studies, as well as the queer movement and theory with their respective spiritual varieties.

\section{The High Position of Germanic Women}

The development of gender images within the early Germanic Faith Movement must be seen in the context of broader gender ideologies around 190o. The late 19th century's obsession with gender difference is well known and researched. It is an era in which gender complementarity, as well as an ideology of separate 
spheres and innate characteristics of men and women, were systematized in a joint effort of academic disciplines (among them biology, anthropology, cultural history) and dispersed through various media: the bourgeois novel, for example. This development reached both a climax and a crisis around 1900 and has been summarized in the famous 'war of the sexes' slogan. It is thus no surprise that the 'woman question' was also taken up by the völkisch movement. Since it was clearly male-dominated, it remained a discourse led "by men, amongst men, and predominantly for men. Women participated merely in the margins." However, as we shall see, some of these women's core ideas would play a role in gender concepts of later Neopagan movements in Germany and beyond.

Two strands of thought became important for concepts of women and femininity within the völkisch religious movement. One was the idea of prehistoric matriarchies first presented by the Swiss classicist Johann Jacob Bachofen (1815-1887) in his seminal 1861 work, "Das Mutterrecht" ('Mother Right'). In suggesting that historical investigation be based on interpreting Greek and Roman myth, Bachofen joined contemporary attempts to find a science-based alternative to theological and biblical concepts of the origin of mankind. He concluded that pre-historic society had developed in three developmental stages: an original hetaric stage of promiscuity and chthonic chaos, which was briefly superseded by bands of warring amazons, to then be overcome by a gynaikocratic (i.e., women-dominated) phase. This first form of social order was eventually replaced by the superior 'father right,' which Bachofen saw as the final goal and zenith of human development. The concept was certainly not intended to be a nostalgic imagination of a better past by the outspokenly anti-liberal Bachofen. Rather, he saw it as proof of the superiority of a male, spiritual 'father right' over a social system bound to material nature, for which women supposedly stood. ${ }^{3}$ Nevertheless, it contained a

2 "ein Diskurs von Männern, unter Männern und vornehmlich auch für Männer. Frauen nahmen daran nur am Rande teil." Uwe Puschner, "Völkische Diskurse zum Ideologem 'Frau," in Völkische Bewegung - Konservative Revolution - Nationalsozialismus. Aspekte einer politisierten Kultur, ed. Walter Schmitz and Clemens Vollnhals (Dresden: Thelem, 2005), 54. Nonetheless, Eva-Maria Ziege, Mythische Kohärenz. Diskursanalyse des völkischen Antisemitismus (Konstanz: UVK, 2002), 216-221, mentions contributions by women activists as well, who (seeing themselves as the guarantors for the preservation of the German or Nordic race) were particularly engaged in the areas of racial hygiene and eugenics.

3 For a discussion of Bachofen's idea cf. Beate Wagner-Hasel, Matriarchatstheorien der Altertumswissenschaft, Wege der Forschung (Darmstadt: Wissenschaftliche Buchgesellschaft, 1992); Claudia Bruns, Politik des Eros. Der Männerbund in Wissenschaft, Politik und Jugendkultur (1880-1934) (Cologne: Böhlau, 2008), 53-74; Brigitte Röder, Juliane Hummel, and 
certain ambiguity, as it implicitly questioned the universality of static gender concepts. The linear-evolutionary model of history favored by Bachofen competed subliminally with a cyclical model of a permanent war of the sexes. ${ }^{4}$ Together with anthropologists of his era, Bachofen's work thus questioned the function of family and reproduction and the nature of social and political structures in general. ${ }^{5}$ This again allowed for its enthusiastic reception by conservative anti-feminists as well as socialist thinkers. Among the latter were Friedrich Engels and Paul Lafargue (Karl Marx' son-in-law), who imagined ancient classless and future socialist societies as matriarchal structures. ${ }^{6}$ It was mainly this strand of reception that anchored the theory of matriarchy read as a social utopia in a broader public imagination. ${ }^{7}$

While Bachofen and the aforementioned socialist thinkers saw the shift from matriarchy to patriarchy as a universal evolutionary process, and thus a drive for social change, for better or worse, others perceived matriarchal and patriarchal social structures as characteristics of certain peoples, races, or cultures. They explained the expansion of patriarchy as the result of migrations and conquest. ${ }^{8}$ This diffusionist model enabled racial readings of theories of matriarchy for which Bachofen's descriptions of the chthonic, oriental nature of gynaikocratic societies had already laid the groundwork. Depending on whether matriarchal systems were viewed as a welcome alternative to modernity or as a despicable sign of its degeneration, they were racialized in different ways. For representatives of the former, among them Ludwig Klages, matriarchy appeared as the basis of the ancient religion of the Aryans or Europeans, which was violently repressed by a despotic, monotheist fathergod of Jewish origin. ${ }^{9}$ For others, for example National-Socialist philosopher Alfred Bäumler, matriarchies appeared as Jewish-oriental systems curbed by

Brigitta Kunz, Göttinnendämmerung. Das Matriarchat aus archäologischer Sicht (Munich: Droemer Knaur, 1996).

4 Bruns, Politik des Eros, 67.

5 Cf. ibid., 6o; Röder, Hummel, and Kunz, Göttinnendämmerung, 30 f.

6 An elaborate discussion on the ambivalence of Bachofen's theories for concepts of gender and family in the 19th century can be found in Walter Erhart, Familienmänner. Über den literarischen Ursprung moderner Männlichkeit (Munich: Wilhelm Fink Verlag, 2001), 70-91.

7 Ziege, Mythische Kohärenz, 203.

8 Cf. Wagner-Hasel, Matriarchatstheorien der Altertumswissenschaft, 310-312, Peter Davies, "'Männerbund' and 'Mutterrecht.' Herman Wirth, Sophie Rogge-Börner and the Ura-LindaChronik," German Life and Letters 6o, no. 1 (2007), 99.

9 Cf. Richard Faber, Männerrunde mit Gräfin. Die 'Kosmiker' Derleth, George, Kiages, Schuler, Wolfskehl und Franziska zu Reventlow. Mit einem Nachdruck des 'Schwabinger Beobachters' (Frankfurt A.M.: Peter Lang, 1994), 51-84; Ziege, Mythische Kohärenz, 208. 
the heroic Indo-Germanic warrior societies - a development that he saw repeated in the downfall of the 'mother right' which ruled the Weimar Republic and the rise of heroic Germanic National Socialists. ${ }^{10}$

The other strand was based on the assumption derived from Tacitus, and popularized by Jacob Grimm: that women enjoyed a particularly high position within Germanic societies, especially as priestesses and seeresses. ${ }^{11}$ This idealizing image has not found much support in recent scholarship, ${ }^{12}$ but it elicited considerable enthusiasm among 19th and 2oth century scholars and Germanophiles who recognized their own ideal of the natural, primordial woman in it. ${ }^{13}$ Jacob Grimm identified the women who were persecuted as witches in early modernity as the last representatives of these pre-Christian wise women. He thus provided another topos eagerly received and elaborated on by anti-Christian völkisch scholars and agitators, for whom the persecuted Germanic woman appeared as the ultimate victim of a violent, male racial Other. ${ }^{14}$

These two strands could be connected through the shared image of the natural, primordial woman and her male "Judeo-Christian" enemy - a constellation which at times culminated in the idea of Germanic women being persecuted and subjugated by Semitic men unable to curb their innate violent sexual drives, with those women being finally rescued by Aryan heroes. Obviously, the German Faith Movement could not avoid engaging with these questions. Ariosophy oscillated between two positions: Jörg Lanz von Liebenfels' violent anti-feminism, which saw women's inclination toward men of lower races as the main reason for the racial degeneration of the Aryans, consequently demanding their strict control; and Guido von List's idea of a Germanic order of maidens, a caste of priestesses. List adopted the idea of the high social position of Germanic women, stylizing their "inward unerring feeling for nature" as the basis for women's priesthood, which was to guarantee the preservation of the pure Aryan race. For him, witches thus appeared as the last

10 Cf. Mythische Kohärenz, 209. Regarding Bäumler, it is interesting to note that he started out as a supporter of Bachofen's 'mother right,' which for him appeared as the religion of the mother giving birth to the divine son.

11 Cf. Julia Zernack, "Germanin im Hauskleid.' Bemerkungen zu einem Frauenideal deutscher Gelehrter," in Kybele - Prophetin - Hexe. Religiöse Frauenbilder und Weiblichkeitskonzeptionen, ed. Richard Faber and Susanne Lanwerd (Würzburg: Königshausen \& Neumann, 1997), 214-224.

12 Cf. Reinhold Bruder, Die germanische Frau im Lichte der Runeninschriften und der antiken Historiographie (Berlin: de Gruyter, 1974).

13 Cf. Zernack, "'Germanin im Hauskleid," 224.

14 Cf. Felix Wiedemann, Rassenmutter und Rebellin. Hexenbilder in Romantik, völkischer Bewegung, Neuheidentum und Feminismus (Würzburg: Königshausen \& Neumann, 2007). 
representatives of these orders of race priestesses, bearers of a sex-magic fertility religion of racial breeding. ${ }^{15}$

The most pronounced völkisch reception of theories of matriarchy can be found in the work of the Dutch-born philologist, historian and musicologist Herman Wirth (1885-1981). His Aufgang der Menschheit (Rise of Mankind, ${ }^{16}$ 1928) offered a grand imagination of an ancient Stone Age culture located in the area of today's arctic. This original anti-materialist, spiritual culture, from which all the world's cultural achievements were derived, was borne by the Arctic-Nordic or Atlantic race. Crucial for Wirth is the assumption that women and mothers played a central role in this Aryan high religion of an All-Mother Earth led by priestesses. A closer look at Wirth's theories reveals nevertheless that his ultimate interest is a "mythic redemption of masculinity,"17 where the figure of the mother is merely considered the venerated source of origin; the eternal womb from which God the Father's son is created and to which he returns in an eternal cycle of birth, death, and rebirth. Wirth's phantasms of a matriarchal Aryan civilization found little support among Germanists and within the German Faith Movement. ${ }^{18}$ However, as we shall see shortly, he gained recognition after World War II as the guru of an incipient Neopagan matriarchy in the 1980 s.

15 Cf. List, The Secret of the Runes, 97f; more references can be found in Stefanie v. Schnurbein, "Weiblichkeitskonzeptionen im neugermanischen Heidentum und in der feministischen Spiritualität," in Das neue Heidentum. Rückkehr zu den alten Göttern oder neue Heilsbotschaft? ed. Otto Bischofberger (Freiburg (сH): Paulus Verlag, 1996), 48 and $67 \mathrm{f}$. See also Puschner, "Völkische Diskurse zum Ideologem 'Frau," 57; Wiedemann, Rassenmutter und Rebellin, 144. The close collaboration between the two Ariosophists points to the fact that they obviously did not see such differences as a grave cause for controversy.

16 The title is formulated as a programmatic alternative to Oswald Spengler's cultural pessimist Decline of the West.

17 Davies, "'Männerbund' and 'Mutterrecht,"' 107. Cf. ibid.; Herman Wirth, Der Aufgang der Menschheit (Jena: Diederichs, 1928), 16-23; Ingo Wiwjorra, "In Erwartung der 'Heiligen Wende.' Herman Wirth im Kontext der völkischen Bewegung," in Utopien, Zukunftsvorstellungen, Gedankenexperimente. Literarische Konzepte von einer 'anderen' Welt im abendländischen Denken von der Antike bis zur Gegenwart, ed. Klaus Geus (Frankfurt A.M.: Peter Lang, 2011); and Ziege, Mythische Kohärenz, 213. The emphasis on the birth of the divine son resembles Alfred Bäumler's early theories. According to Stefan Breuer, a similar ideological constellation can be found in the theories of Conservative Revolutionaries in general. Celebrating a masculinist, warrior heroism, they imagined the potential for a rebirth or regeneration of the nation in a "maternal soil, a pre- and super-individual unity of the feminine coded stream of life." Breuer, Anatomie der konservativen Revolution, 80.

18 Wirth's significance for academic thought will be discussed in Chapter 8. 
The opposite is the case for another variety of the topos of an allegedly high social position of Germanic women. The idea that these women were both the equals of heroic men and mothers of heroes became popular in German research on saga literature from the early 2oth century on. Arthur Bonus, the proponent of a 'Germanization of Christianity,' seems to have been the first to propose the idea that it is not the legal position of women (which appears as rather dismal in medieval Icelandic legal sources), but rather her high moral position which guaranteed equality of the sexes in Germanic history. ${ }^{19}$ Germanist Bernhard Kummer in particular rejected Wirth's view of a mother earth cult as a construct with Semitic tendencies, postulating that Germanic society constituted neither a matriarchy nor a patriarchy. Downplaying gender difference and emphasizing racial difference, Kummer saw Germanic society as an agrarian idyll in which both men and women 'tilled the native soil' and defended it as 'heroes,' 'heroines,' and 'mothers of heroes,' thus securing the future of the pure Germanic race. This idealized old Germanic society served, for him, as proof that "mothers are most venerated, marriages bear most children and are most healthy, where the sexes stand in equal faith and equal morals before their gods and goddesses." ${ }^{20}$ It furthermore seems significant that this ideal of "comradeship and equality" 21 was distinguished by a lack of eroticism and a 'natural' sense of chastity, values seen as the positive antitheses to French, Roman, and Jewish promiscuity and eroticism. ${ }^{22}$

In spite of these contradictory approaches, List, Wirth, and the saga researchers share a number of basic positions: First, the general idea of a veneration of women, who occupy a high social and religious position in Germanic societies. Second, the idea of men and women sharing values, but being responsible for separate, complementary spheres - an expression of the widespread ideas on gender complementarity of the era. Third, their agreement on the respective gender system's main purpose - the continuation of the Germanic or Nordic race. And finally, their vehement anti-Christian and

19 Zernack, "'Germanin im Hauskleid," $217 \mathrm{f}$.

20 Bernhard Kummer, Die weibliche Gottheit bei den Germanen (Leipzig: Adolf Klein, 1933), 32: "dort [sind] die Mütter am höchsten geehrt, dort die Ehen am kinderreichsten und gesündesten, wo die Geschlechter im gleichen Glauben und gleicher Sitte vor ihren Göttern und Göttinnen stehen.”

21 "Die Bedeutung des altnordischen Schrifttums für Religionsgeschichte und Missionskunde," Zeitschrift für Missionskunde und Religionswissenschaft 43, no. 10, 11 (1928), 297

22 Cf. the more elaborate discussion in Zernack, “'Germanin im Hauskleid," 223-225. 
anti-Jewish affect, which blamed Christianity for having destroyed this idealized system of gender harmony and racial purity. ${ }^{23}$

In Chapter 6, I argued that nature religion in contemporary Asatru has to be understood as an idiosyncratic blend of German Faith concepts of an immanent Germanic religion with general Neopagan and eco-spiritual ideas. There is a similar operation at play in the conceptions of gender and sexuality within modern Asatru. They have also been informed by more recent spiritual movements, not least spiritual feminist scholarship on matriarchies, as well as witchcraft and goddess worship, which all emerged as parts of second-wave feminism during the 1970 a and 8os. The motives of feminists who turned their beliefs to ancient matriarchies, with their supposed worship of a great earth goddess or several female deities, are certainly quite different from the motives of the Germanic revival. However, the two movements share the desire to create a historical myth, an invented past in which a positive vision for the future can be anchored. And, as we shall see, the difference in motives does not immunize feminist spirituality against an echoing of Germanophile ideas.

Feminists of the 1970s began to look at theories of ancient matriarchies and their overthrow by patriarchal structures in order to find both "an adequate

23 Julia Zernack and others have shown that the main motivation for the emergence of this idealized image of Germanic women seems to have been to prove the moral superiority of Germanic culture and religion over Christianity. Thus, the contradictory sources had to be interpreted in a selective way. The main problem which saga researchers in particular were faced with was the fact that legal documents from the Christian era showed a slight increase of women's rights to consent in marriage as well as self-determination in legal matters compared to earlier laws from pre-Christian times. At the same time, the literary descriptions of women in some of the Icelandic sagas indeed show an astonishing number of self-reliant, active women characters. Instead of reading these literary accounts as either literary topoi or projections of contemporary attitudes into the past, Gustav Neckel, for example, ignored such contradictions and insisted on reading the legal sources as normative documents, which had little to do with the actual conditions and practices that in his eyes had persisted from Tacitus' times well into the Middle Ages, until Christianity destroyed this system, Gustav Neckel, Liebe und Ehe bei den vorchristlichen Germanen (Leipzig: Teubner, 1932). For refutations of the myth of a better position of Germanic women before the advent of Christianity see e.g. Jenny Jochens, "Consent in Marriage. Old Norse Law, Life, and Literature," Scandinavian Studies $5^{8}$ (1968), Rolf Heller, Die literarische Darstellung der Frau in den Isländersagas (Halle: Niemeyer, 1958), Judith Jesch, Women in the Viking Age (Woodbridge: Boydell Press, 1991), as well as Zernack, "Germanin im Hauskleid," 222 f. For a discussion of theories of continuity and their employment within Germanic Neopaganism see Chapter 8. 
explanation for the existence and persistence of male dominance,"24 as well as a model of orientation for the creation of a better future, "a time of peace, ecological balance, and harmony between the sexes, with women either recovering their past ascendancy, or at last establishing a truly egalitarian society under the aegis of the goddess."25 The feminist spirituality movement combined the idea of matriarchies with both the belief in a great goddess, who had supposedly been worshipped in pre-Christian times, and the belief in a version of modern witchcraft, which saw women as the guardians of such ancient cults due to women's supposed proximity to nature and its magic. Already during the re-emergence of such beliefs in the 1970s and 8os, these ideas had been widely dismissed by classicists and archaeologists. ${ }^{26}$ Moreover, they were criticized for reproducing stereotypical 19th-century gender concepts, the purpose of which had been to stabilize their own era's ideology of gender complementarity. Nonetheless, the old idea of women's proximity to nature and materiality was embraced and revaluated as a positive (and eco-friendly) quality, a sign of superiority rather than inferiority. The same was true for women's alleged magical skills and irrationality. Critics rejected such concepts as a biologistic recurrence of a dangerous (menstrual) blood and earth mysticism. ${ }^{27}$

For our context, it seems important that notions of race and culture implicit in older theories were partially transferred to more recent feminist contexts. Many goddess worshippers and matriarchy theorists worked on the assumption that Judaism and its monotheistic successors had overthrown the original matriarchies and thus 'murdered the goddess' - a new variety of the old

24 Cynthia Eller, "Relativizing the Patriarchy. The Sacred History of the Feminist Spirituality Movement," History of Religions 30, no. 1 (1990), 281.

25 The Myth of Matriarchal Prehistory. Why an Invented Past Won't Give Women a Future (Boston: Beacon Press, 2000), 3.

26 For comprehensive summaries of such refutations from feminist perspectives see for example Wagner-Hasel, Matriarchatstheorien der Altertumswissenschaft; Eller, The Myth of Matriarchal Prehistory.

27 Cf. Schnurbein, "Neuheidnische Religionsentwürfe von Frauen"; Susanne Lanwerd, "Zur Bedeutung von 'Feministischer Spiritualität' in der Literatur des New Age," in Die Religion von Oberschichten. Religion - Profession - Intellektualismus, ed. Peter Antes and Donate Pahnke (Marburg: diagonal-Verlag, 1989); "Im Namen der Göttin? Überlegungen zur Faszinationskraft antiker Göttinnenbilder," in Kybele - Prophetin - Hexe. Religiöse Frauenbilder und Weiblichkeitskonzeptionen, ed. Richard Faber and Susanne Lanwerd (Würzburg: Königshausen \& Neumann, 1997), Kerstin Lück, "Der Wunsch nach Verzauberung. Religionswissenschaftliche Überlegungen zur 'spirituellen Frauenbewegung," in Kybele - Prophetin - Hexe. Religiöse Frauenbilder und Weiblichkeitskonzeptionen, ed. Richard Faber and Susanne Lanwerd (Würzburg: Königshausen \& Neumann, 1997). 
Christian anti-Jewish stereotype of the Jews as 'god killers' with roots both in the small völkisch women's movement ${ }^{28}$ as well as in the Socialist psychoanalyst and matriarchy theorist Otto Groß' ideas. ${ }^{29}$ Anti-Jewish and racist ideas entered feminist spirituality through an uncritical adoption of ethnicist diffusionist theories of matriarchy as well. In her 1971 classic of feminist spirituality, The First Sex, American librarian Elizabeth Gould Davis drew on the theories of Bachofen and promoters of a Northern or Atlantic origin of culture to prove that a "blue-eyed, golden- or red-haired race of people" 30 originating in a "subarctic locale,"31 whose last survivors she imagined to be the Celts, had spread matriarchal civilization across the world. This ancient "non-Aryan," "nonSemitic" race of unknown origin ${ }^{32}$ was later overthrown by the "mammoths of masculinism - Teutonic barbarism and Semitic Christianity."33

This somewhat idiosyncratic combination of feminist anti-Indo-European and anti-Semitic theory relies on the work of Lithuanian archaeologist and Indo-Europeanist Marija Gimbutas (1921-94). From the 1950s on, Gimbutas combined Indo-European scholarship and theories of matriarchy to suggest that the peaceful matriarchal systems of "Old Europe" had been overrun by patriarchal Indo-European horsemen from the steppes north of the Caucasus, a culture she called 'Kurgan. ${ }^{34}$ Both traditional and feminist archaeologists tended to regard her theory as methodologically flawed, and as an unsupportable projection of current political values into a pre-historical past. ${ }^{35}$ As she lost support within her academic field, from the 1980 os on Gimbutas increasingly directed her work to an inexpert general public, "remodel[ing] the image

28 The idea of a Jewish origin of patriarchy, that "the Jewish man robbed woman of priesthood," existed already within the small völkisch women's movement in the early 2oth century. Cf. Ziege, Mythische Kohärenz, 185-19o, quote p. 188.

29 Cf. Faber, Männerrunde mit Gräfin, 42-50.

3o Elizabeth Gould Davis, The First Sex (New York: Putnam, 1971), 25 f.

31 Ibid., 22.

32 Ibid., 26.

33 Ibid., 207.

34 Cf. Lynne Meskell, “Goddesses, Gimbutas and 'New Age' Archaeology," Antiquity 69 (1995), Ronald Hutton, "The Neolithic Great Goddess. A Study in Modern Tradition," Antiquity 71 (1997), Arvidsson, Aryan Idols, 288-293.

35 As many of her critics have pointed out, her perception of violent Eastern hordes overrunning a peaceful Old Europe may well have been a reflection of her own experience of the Baltic States' occupation, first by the Germans, and then the Soviets. See e.g, Meskell, "Goddesses, Gimbutas and 'New Age' Archaeology," 78f; Stefan Arvidsson, Ariska Idoler. Den indoeuropeiska mytologin som ideologi och vetenskap (Stockholm/Stehag: Brutus Östlings Bokförlag Symposion, 2000), 291. 
of [the great goddess] to conform with evolving feminist opinion." ${ }^{36}$ Employing a "language of revelation," ${ }^{37}$ she ended her life as the "avatar of a rediscovered religion."38 It is worth mentioning that Gimbutas also injected an anti-Jewish notion into her theories by claiming the genetic and cultural relatedness of Indo-Europeans and Semites (hence the idea of a "Teutonic-Semitic patriarchy"). It should therefore not come as a surprise that in the context of German feminist and eco-feminist spirituality, the work of Herman Wirth was also enthusiastically received. ${ }^{39}$

Ideas of matriarchy have always had a tense relationship to German Faith and Asatru, both because of their potential disruption of traditional gender orders, and more recently because of the monotheistic framework in which the cult of the 'one great goddess' operates. Nevertheless, there have been interactions, not only through the adoption of Germanic Neopagan ideas into feminist spirituality, but also vice versa. In the 1980 s, this tendency was most pronounced in German Asatru. Sigrun von Schlichting, from the racial-religious Armanen-Orden, in particular based her renewal of Ariosophic doctrine on Herman Wirth's theories. She emphasized the significance of the Norse goddesses, to whom she assigned the areas of fertility, birth, and growth, as well as healing, family, and kin, reiterating the idea of Germanic woman being the preserver and guardian of a "pure Germanic race." ${ }^{40}$

Notions of an ideal gender balance in Heathenism were also promoted by other Asatru groups. For the Heidnische Gemeinschaft, the persecution of the witches, the "wise Germanic women," provided a welcome opportunity to formulate their radical anti-clericalism. ${ }^{41}$ Adoptions of elements from Wicca and feminist spirituality became fairly frequent in other varieties of international Asatru as well. An influential figure has been Diana Paxson, long-term active member of The Troth in the USA, who also worked as an officer in the Covenant of the Goddess and founded the Fellowship of the Spiral Path

\footnotetext{
36 Hutton, "The Neolithic Great Goddess," 97.

37 Ibid., 89.

38 Ibid., 89 .

39 Cf. Schnurbein, "Weiblichkeitskonzeptionen im neugermanischen Heidentum und in der feministischen Spiritualität," 62 .

40 Cf. ibid., $50 \mathrm{f}$.

41 In the flyer "Hexen - weise Frauen" (Witches, wise women), the editor of the journal Runenstein propagated the practice of "our heathen religion" as an antidote to the "hatred of perverse, unnatural clerics against everything female." (Haß widernatürlich lebender Kleriker gegen alles Weibliche). Cf. http://www.runenstein-net.de/hexen.htm, last accessed August 25, 2014.
} 
(a pan-Pagan association in California promoting different versions of reconstructed European Paganism, together with Earth and goddess spirituality). ${ }^{42}$ Through her collaboration with feminist witch Zsuzsanna Budapest ${ }^{43}$ and her sister-in-law Marion Zimmer Bradley,44 Paxson's views on Paganism, women's rituals, and spirituality have exerted significant influence on the general perception of Asatru.

Consequently, adoptions of individual elements of women-centered spirituality can be found in most Asatru groups today. They are generally accepted as valid parts of Germanic spirituality, as long as they do not display their debts to Wicca too overtly. There is an almost unanimous, although rather vaguely formulated consensus that women indeed held a high social position in Nordic societies, that the influence of Christianity is to blame for that high regard's demise, ${ }^{45}$ and that contemporary Western societies' principles of equality and justice are to be attributed to the survival of such Heathen traditions. ${ }^{46}$ The reasons why these opinions are so rarely questioned within Asatru must be sought in the fact that they are also so widespread in other milieus, for example, in the spiritual women's movement or in eco-spirituality, and that they have found their way into idealizing (self-)perceptions of the Scandinavian countries. They have become part of a Scandinavian exceptionalism, according the North a particular tradition of equality and justice. It is thus easy to reconfigure the older stereotype of the high position of women in the pre-Christian North as a means of granting this modern exceptionalism a deep historical basis. ${ }^{47}$ In his popular account of Scandinavian mythology, Lars Magnar Enoksen, a

42 Cf. http://www.thespiralpath.org/, last accessed August 25, 2014.

43 Cf. Zsuzsanna Budapest and Diana L. Paxson, The Celestial Guide to Every Year of Your Life. Discover the Hidden Meaning of Your Age (Newburyport, MA: Red Wheel/Weiser, 2003).

44 Paxson provided information about Pagan women's rituals (cf. Marion Zimmer Bradley, The Mists of Avalon (New York: Knopf, 1983), Acknowledgements) to Bradley's The Mists of Avalon and co-authored and later authored the sequels of the series.

45 Examples could be found in almost all the groups discussed here and in most of their publications, cf. for example Jennings, The Norse Tradition, 18; GardenStone, "Gleichberechtigung und Asatru," Herdfeuer. Die Zeitschrift des Eldaring e.V. 6, no. 20 (2008), 25.

46 Cf. Jennings, The Norse Tradition, 18.

47 For discussions of Nordic exceptionalism and its "regimes of goodness" see Christopher S Browning, "Branding Nordicity. Models, Identity and the Decline of Exceptionalism," Cooperation and Conflict 1 (2007); Lasse Koefoed and Kirsten Simonsen, "The Price of Goodness. Everyday Nationalist Narratives in Denmark," Antipode 2 (2007); Katarina Schough, Hyperboré. Föreställningen om Sveriges plats i världen (Stockholm: Carlsson Bokförlag, 2008); Mai Palmberg, "The Nordic Colonial Mind," in Complying with Colonialism. Gender, Race and Ethnicity in the Nordic Region, ed. Suvi Keskinen, et al. (Farnham/Burlington, vT: Ashgate, 2009); Nina Witoszek, The Origins of the 'Regime of Goodness.' Remapping the Cultural History of Norway (Oslo: Universitetsforlaget, 2011); 
self-taught rune specialist and enthusiast of the Nordic pre-Christian Middle Ages, summarizes the images of women and gender which lie behind the idea that political ideals of equality and justice originate in Norse religion:

But if we turn our gaze to the Scandinavian mainland, the biggest difference in relation to the rest of the world is that women's position here is stronger than any other place in public life. This fact has ancient ancestors and is something foreign religions of dominance have never been able to crush, in spite of persistent attempts throughout the centuries. In Pagan society, woman was equal with man on all levels, and in some areas, woman stood stronger than man. [...] Myth is always a direct reflection of the society it lives in, and the goddesses' unrestricted position and superiority in numbers can be seen as a mirror image of the social culture which gave rise to Norse mythology. Although woman's position in today's North is better than in many other countries and cultures, it is not as strong as it was in Pagan times. ${ }^{48}$

In this quote, we can find all the methodologically and historically problematic assumptions that had already vexed Germanophile scholarship in the 1930s and earlier, as well as feminist spirituality later on: The questionable idea that myth mirrors social structures, a lack of source criticism, unsupportable theories of continuity between pre-historic past and present society, not to mention the unfounded claims about the superiority of goddesses in the Norse pantheon. ${ }^{49}$ It is also an example of how modern feminist ideas can be integrated into Asatru.

It thus makes sense that elements of 1930s scholarship, for example the bourgeois scholarly fantasies about Germanic women and their allegedly equal

Ebbe Volquardsen, Die Anfänge des grönländischen Romans. Nation, Identität und subalterne Artikulation in einer arktischen Kolonie (Marburg: Tectum, 2011), 37-43.

48 Lars Magnar Enoksen, Norrøne guder og myter, trans. Kåre A. Lie (Oslo: Schibsted Forlag, 2008), 211: "Men om vi vender blikket mot det skandinaviske fastlandet, er den største forskjellen i forhold til den øvrige verden at kvinnens stilling er sterkere her enn noe annet sted i det offentlige livet. Dette faktum har urgamle aner og er noe som utenlandske herskerreligioner aldri har klart å knuse, til tross for iherdige forsøk gjennom århundrene. I det hedenske samfunnet var kvinnen likestilt med mannen på alle plan, og på noen områder sto kvinnen sterkere enn mannen. [...] Myten er alltid en direkte gjenspeiling av det samfunnet den lever i, og gudinnenes uinnskrenkede stilling og overlegenhet $i$ antall kan ses som et speilbilde av den samfunnskulturen som ga opphav til den norrøne gudelæren. Til tross for at kvinnens stilling i dagens Norden er bedre enn i mange andre land og kulturer, er den likevel ikke like sterk som den var i hedensk tid."

Such widespread methodological flaws are discussed in Chapter 8. 
position in marriage and custom developed by writers such as Gustav Neckel and Bernhard Kummer, re-emerge in Asatru contexts. A case in point is the eighty-page discussion of Germanic conceptions of marriage and the legal position of women by Eldaring member Christian Brüning, published in Heidnisches Jahrbuch. ${ }^{50}$ The author brazenly ignores all post-1945 scholarship demonstrating how the legal position of women improved with the arrival of Christianity. He points instead to the works of Neckel and Kummer and their thesis of morals (Sitte) predominating over legal texts. Matthias Wenger, another German Asatruer, started out as a supporter of the racial-religious Armanenorden, but then adopted an outspoken a-racist stance in the 1990s. ${ }^{51}$ Nevertheless, he remains equally faithful to the ideas of both Bernhard Kummer and Herman Wirth, while omitting their affiliation to racist thought and National Socialism. ${ }^{52}$ Herman Wirth's theories on Germanic matriarchies have made their way into American Asatru contexts as well. The "Ura-LindaChronik," or Oera Linda Book as it is called in English, an allegedly ancient history of a Frisian family, which was uncovered as a forgery early on, and which Wirth used to support for his own ideas, ${ }^{53}$ appears on several American Asatru sites. ${ }^{54}$ Theories of a Germanic or pre-Indo-European matriarchy, on the other hand, have decreased in significance within contemporary Asatru. There are, however, exceptions on all sides of the spectrum. German Asatru author GardenStone, for example, supports the idea that Europe was ruled by

5o Christian Brüning, "Das Eheverständnis der Germanen und die rechtliche Stellung der Frau," Heidnisches Jahrbuch 3 (2008).

$5^{1}$ Matthias Wenger, "Meine politische Position und ihre Entwicklung in 30 Jahren - eine Dokumentation," Der HAIN - Das Magazin für natürliche Religion und gesellschaftliche Wandlung, http://www.derhain.de/, last accessed December 04, 2011.

52 Cf. Matthias Wenger, "Patriarchalische Ideologie oder matriarchalisches Wertsystem. Die Auseinandersetzung um Herman Wirth und die Ura-Linda-Chronik," Der HAIN - Das Magazin für natürliche Religion und gesellschaftliche Wandlung, http://www.derhain.de/ WirthMatriarchat.htm, last accessed May 29, 2015, cf. also Chapter 8 regarding Wenger's reception of Wirth and Kummer.

53 Cf. Hunger, Die Runenkunde im Dritten Reich, 181; Davies, “Männerbund' and 'Mutterrecht." Cf. also Chapter 8.

54 According to a Pagan Wiki, it "has been influential in the development of modern Paganism, and Odinism and Asatru in particular." http://pagan.wikia.com/wiki/Oera Linda_Book, last accessed August 25, 2014. The page does not offer any evidence for this claim. However, on the eclectic homepage of the Alternative Religions Educational Network (AREN), the Asatru section lists links to the Oera Linda Book (http://www.aren .org/prison/documents/Asatru.htm). Prudence Priest, former member of the $A F A$, the Ring of Troth, and current head of Yggdrasil, refers to it as an important source in interviews. Cf. SilverWitch, "Just 'Wiccatru' Folk." 
matriarchies until around $2200 \mathrm{BC}$, but warns against idealizing them, rejecting the thesis that women-centered societies, with their 'passionate,' 'emotional, and possibly more fearsome Amazons, were more peaceful. ${ }^{55}$ In contrast, Danish Starkad Storm, in his vicious attacks on monotheism's "enmity towards nature and life" discussed in Chapter 5 , idealizes woman as the "lifegiving and (most) natural" human, claiming: "In polytheistic and primordial cultures, woman was honored, respected and outright venerated as bearer of the sacred life - not to speak of regular matriarchies." In a manner that is fully compatible with Ariosophic, völkisch and biology-based feminist spirituality, he continues: "It has been decisive for world-negating monotheism to portray woman as bad and sinful, as she is the (most) sexual being, and due to menstruation as the physical expression of the lifecycle." Not surprisingly, his conclusion is anti-Islamist, as are his other invectives: "In the Muslim world, abuse of women is in some cases the duty of orthodoxes and is enforced fanatically." 56

One effect of the consensus of a high religious position of Germanic woman is the equally widespread, unquestioned opinion that women can and should hold leading positions within Asatru groups and function as leaders of rituals. ${ }^{57}$ At the same time, the alleged equality of the sexes in Asatru is very rarely based on an idea of equality. Most Asatruers assume natural differences between men and women, assign them separate areas of expertise and ability, and defend complementary gender relationships. This widespread attitude is mirrored in many descriptions of marriage and coming of age rituals. The Asatru manual Our Troth emphasizes the equality of the sexes in order to describe different rituals for 'man-making' and 'woman-making' that are based on assumptions of the different physical features of men and women. The chapter on woman-making concludes:

55 GardenStone, "Gleichberechtigung und Asatru," $23 \mathrm{f}$.

56 Stensgaard, “Om Monoteismens Uvæsen 2," 21: "Kvinden har i de polyteistiske og oprindelige kulturer været æret, respekteret og ligefrem tilbedt som bærer af det hellige liv - for ikke at tale om regulære matriarkater." "Som det (mest) seksuelle væsen og i kraft af menstruationen det kødelige udtryk for livscyklus, har det været afgørende for den verdensforsagende monoteisme at gøre kvinden ond og syndig." "I den muslimske verden er kvindemishandling i vise tilfælde de rettroendes pligt, som vogtes nidkært."

The only exception I have found is Theodism. Garman Lord agrees with Asatruers that "women are always understood to have the same natural rights as men have" and acknowledges the possibility that women can hold leading positions. Nevertheless, he considers it uncommon and problematic, because it is man who is "always theoretically an armsbearer, and inherent in manhood is the principle of the potential use of force as an instrument as policy." Lord, The Way of the Heathen, 61. 
It will be noticed that the woman-making seems less traumatic than the man-making, with less emphasis on the sharp change of status, the death and rebirth elements, and so forth. This is because all of these things are already going on inside the woman's body. Whereas the man-making is a single intense spiritual/social change, the woman-making is put forth as a somewhat slower and gentler spiritual/social change designed to integrate the single intense physical event which transforms a girl into a woman. ${ }^{58}$

The fact that one of the first acts of the newly initiated woman is to present the drinking horn to the men who re-enter the ritual space indicates that woman's role is also seen here in a fairly traditional way: as the symbolic nourisher of men and keeper of the house.

In his suggestion for a celebration of majority in the ethnicist German $V f g H$, Fritz Steinbock makes a similar argument. While he recommends identical ceremonies for both sexes, he suggests a different closure where a distinction is made between men's and women's realms: The father is supposed to speak a prayer for the young man, invoking male deities and emphasizing male tasks, such as providing for and protecting the family. The mother's prayer for the young woman is directed at female deities and invokes woman's role as lady of the house, wife, and mother, focused on home, kin, fertility, and healing. ${ }^{59}$

Danish Asatruer Viktoria Gotved discusses what it means that women receive a key in the wedding ceremony:

This does not suggest that women should return to the meat pots, but it does entail an acknowledgment that the sexes are different and each have their strengths and weaknesses. How one then chooses to distribute labor in everyday life is everybody's own affair. ${ }^{60}$

The emphasizing of traditional gender differences, while simultaneously relegating alternative models to the private realm, is widespread in Asatru. It can be understood as a strategy to counter the undeniable fact that Asatru is still strongly dominated by men, with regard to both membership and leadership.

$5^{8}$ Gundarsson, Our Troth, vol. II, 263.

59 Steinbock, Das heilige Fest, 153.

6o Gotved, Asatro. De gamle guder i moderne tid, 68: "Det ligger ikke i dette, at kvinderne skal tilbage til kødgryderne, men dog en anerkendelse af, at kønnene er forskellige og hver har sine stærke og svage sider. Hvordan hver især vælger at fordele arbejdet i hverdagen, er deres egen sag." 
An equal gender ratio can only be found in a-racist groups that strongly deemphasize natural differences between the sexes, such as the Norwegian Bifrost, the very small German Nornirs Ett, and the Danish NTF. This points to the fact that the traditional gender concepts found within Asatru are not overly attractive for women, especially when one considers that women have a stronger presence in many other religious contexts, be they alternative, Christian, or Jewish.

\section{Masculinity and Männerbund}

The idea that natural differences between men and women are encoded in Norse myth or "Heathen mysteries," 61 and that each sex can and should exercise their own modes of spirituality and ritual, has led to an interest in specifically male forms of Heathen religious practices. A programmatic example is found in the last chapter of Björn Ulbrich's 1990 book, "Cult and Rite of the Heathen Community." 62 Ulbrich, the founder of the German Arun publishing house, ${ }^{63}$ ends his book with a chapter on women's moon rituals and men's male bonding and blood-brotherhood rituals. He ascribes these different modes of spirituality to physiological features and their alleged spiritual equivalents - an association which reverberates in many Asatru contexts today. He writes:

We sense the nature of the moon only vaguely within us, and men seem to be less able to resonate with it than women. [...] The sun-cult is considered a manifestation of a masculine-influenced sun veneration, because it is in need of an intellectual spirituality in order to become institutionalized. [...] The gently hazy, but all the more sustainable, character of this [the moon's] planetarian energy finds its ideal complement and fulfillment of its nature in the female body. Female rites of consecration and initiation thus concentrate the mind on the cycle of the moon. In contrast to the male initiation, they require less of an orgiastic climax or outbreak of violent energy, but rather need steady and cyclical work in line with both nature's rhythm, and that of a specific femininity. ${ }^{64}$

\footnotetext{
$61 \quad$ Oertel, "Was ist Heidentum?"

62 Ulbrich, Im Tanz der Elemente.

63 See Chapter 2.

64 Ibid., 451f: "Wir spüren das Wesen des Mondes nur diffus in uns und Männer scheinen zu weniger Resonanz auf die Schwingungen fähig als Frauen [...] Der Sonnenkult gilt [...] als
} 
During the 1920 and 30s, similar theoretical postulations led to the reception and transformation of German theories of all-male societies, the Männerbünde, which merge with ideas adopted from the spiritual men's movement in modern day Asatru.

The term Männerbund refers to all-male warrior associations in so-called primitive societies; it is rarely translated into other languages, but is used rather as an international ethnological term. ${ }^{65}$ It was coined in 1902 by the German ethnologist Heinrich Schurtz, in his book "Altersklassen und Männerbünde. Darstellung der Grundformen der Gesellschaft"66 ("Age-Classes and All-Male Associations. Presentation of the Basic Forms of Society"). Schurtz investigates various male-only phenomena, such as men's houses or boys' intitiation associations. His findings led him to claim that men have a stronger instinct for sociability (Geselligkeitstrieb) than women, and that boys need rites of initiation in order to ensure their separation from the mother and the maternally dominated realm of the family. This in turn allows them to be able to fulfill their role as creators of larger social formations. ${ }^{67}$ In his analysis, Schurtz engaged with theories of matriarchy, offering an alternative explanation for the origin of society and the state, which placed men back at the center of academic attention. ${ }^{68}$ Similar to Bachofen's theory of matriarchy, Schurtz's

Erscheinungsform einer männlich beeinflußten Sonnenverehrung, da er der intellektuellen Geistigkeit bedarf, um sich zu institutionalisieren. [...] Der zart-diffuse, aber umso nachhaltigere Charakter dieser planetarischen Kraft [des Mondes] findet im weiblichen Körper die ideale Ergänzung und Erfüllung seines Wesens. Weibliche Einweihungs- und Initiationsriten konzentrieren daher das Bewußstein auf den Zyklus des Mondes und verlangen im Gegensatz zu männlichen Einweihung weniger einen orgiastischen Höhepunkt oder den Ausbruch gewalt-iger Energie, sondern bedürfen einer stetigen und zyklischen Arbeit im Rhythmus der Natur und der spezifisch eigenen Weiblichkeit."

65 The most comprehensive and up-to-date discussion of German theories of Männerbund between 1880 and 1934 can be found in Bruns, Politik des Eros, on which much of the following summarizing discussion is based.

66 Heinrich Schurtz, Altersklassen und Männerbünde. Eine Darstellung der Grundformen der Gesellschaft (Berlin: Reimer, 1902).

67 Rather than following this essentialist assumption of a basic 'nature' of masculinity, Schurtz's theory should be read as a "social new invention" (Ulrike Brunotte, "Der Männerbund zwischen Gemeinschaft und Gesellschaft. Communitas und Ritual um 190o" in Diskurse des Theatralen, ed. Erika Fischer-Lichte, et al. (Tübingen/Basle: A. Francke, 2005), 233) engaging with the contemporary theories of matriarchy discussed above in an explicitly anti-feminist manner, cf. Bruns, Politik des Eros, 62; see also See, Barbar Germane Arier, 318.

68 Bruns, Politik des Eros, 99; cf. also Brunotte, "Der Männerbund zwischen Gemeinschaft und Gesellschaft. Communitas und Ritual um 1900," 236. 
approach can be read as both a cure for, and a symptom of, current social uncertainties and anxieties about gender identities and relations. A cure because it naturalized men's function as leaders of state and society, and a symptom because it implicitly demonstrated that masculinity needed to be produced through ritual and thus could not be as self-evidently natural as Schurtz himself assumed it to be.

Schurtz's ideas on male bonding had an impact on later theorists of the Männerbund in Germany. They manifested in the form of a rebellion against both patriarchal and maternal forces. In his idiosyncratic analysis of the German outdoor youth movement Wandervogel,69 Hans Blüher (1888-1955), the foremost popularizer of Männerbund-theories in Germany, explained the attraction of this movement for young men through references to Schurtz, to Sigmund Freud's theory of the sexual drive, and to the misogynist writer Otto Weininger's concept of an original human bisexuality. Aligning theories of the Männerbund with the era's youth cult, he implicitly configured 'youth' as 'male.70

According to Blüher, the youth movement was driven by a (sublimated) homoerotic eros projected onto the charismatic leader of the respective Männerbund - a savagely contested thesis, which nevertheless was able to fulfill two social needs at the time:

The idea of a (homo)erotic bonding between men did not only help to develop forms of a modern and more emotional masculinity, but also to guarantee them a greater political influence. The discourse of the Männerbund defended an exclusively male understanding of the state and simultaneously effectively denied the right of political participation for women and Jews. ${ }^{71}$

By positing the homoerotically charged Männerbund instead of the family as the origin of the state, Blüher attempted to reevaluate homosexuality in a radical manner. ${ }^{72}$ Contrary to similar developments in British and American

$69 \quad$ Hans Blüher, Wandervogel. Geschichte einer Jugendbewegung, 3 vols. (Berlin: Weise, 1912).

70 Bruns, Politik des Eros, 164.

71 From the back cover of ibid.: "Die Vorstellung vom (homo)erotischen Bündnis unter Männern half nicht nur, Formen einer modernen und gefühlvolleren Männlichkeit zu entwickeln, sondern diesen auch politisches Gewicht zu verleihen. Der Männerbunddiskurs verteidigte ein exklusiv männliches Staatsverständnis und sprach zugleich wirkungsvoll Frauen und Juden das Recht auf politische Partizipation ab."

72 Blüher's take on homosexuality was based on Adolf Brand's masculinist Gemeinschaft der Eigenen (Association of the Self-Owned), which sought an alternative to the theninfluential Magnus Hirschfeld's medical and implicitly pathologizing approach. 
masculinist homosexual movements, Blüher's ideas took an anti-egalitarian, anti-feminist, and Romantic nationalist turn. ${ }^{73}$ His later works added an increasingly aggressive, militant, and anti-Semitic interpretation of the Aryan Männerbund, in which he now saw proof that homoeroticism was not a moral issue in Aryan society, but was condemned only after the arrival of Semitic monotheism..$^{74}$

The focus on homoerotic forces made Blüher's theory highly controversial, and it solicited partially outraged reactions from supporters of the völkisch movement and religion, whose ideology was based on furthering the Aryan race. ${ }^{75}$ Nevertheless, it captured the experience of bonding in the liminal space of nature that many young men of the youth movement shared, and which was also present in the German militant right-wing corps (the Freikorps), ${ }^{76}$ as well as in other militant right-wing groups. The experience of World War I further emphasized the notions of sacrifice and death that had been present in theories of the Männerbund all along. These notions were now understood in a much less symbolic, but more concrete and contemporary way: as a cult of the union with fallen comrades, centered upon the cruel experience of the trenches. In this context, the Männerbund was seen as the militant answer to the despised democratic republic allegedly ruled by female, Jewish, and Bolshevik forces.

The idea of the Männerbund as the foundation for the modern state, with roots in a deep past, and as symbolic of the natural character of men, was thus cemented in the German public imagination after World War I. It is against this background that the folklorists and Germanists Lily Weiser and Otto Höfler developed their ideas about the existence of initiatory guilds and

73 Bruns, Politik des Eros, 164. For the reception of Blüher's ideas in general cf. ibid., 327-382.

74 Cf. especially Hans Blüher, Die Rolle der Erotik in der männlichen Gesellschaft. Eine Theorie der menschlichen Staatsbildung nach Wesen und Wert., 2 vols., vol. I (Der Typus Inversus), vol. II (Familie und Männerbund) (Jena: Diederichs, 1919). Cf. Bruns, Politik des Eros, 324-330. For a reception of Blüher's ideas within Radical Traditionalism cf. also Robert Black, "Fidus, Brand, and Bluher. New Paths for Eroticism," Living Traditions. A Magazine of Radical Traditionalism, Esotericism, Perennialism, Mysticism, Politics and Social Issues 4, no. 2 (2011).

75 Cf. Bruns, Politik des Eros, 363. However, it seems significant that none of Blüher's critics questioned his demand to exclude women and girls from the Wandervogel; evidence that misogynist ideologies were at work on both sides of the spectrum. Ibid., 339.

$7^{6}$ The Freikorps were formed by German wwi veterans after the demilitarization of Germany and fought the Soviet republics which briefly emerged around 1918/19 in several parts of Germany. 
male-only secret warrior bands in ancient Germanic societies. They based their concepts on Schurtz's theories, as well as on theories of religious experience developed by Jakob Wilhelm Hauer. ${ }^{77}$ In this process, homoerotic notions were downplayed significantly. In his 1934 work, "Kultische Geheimbünde der Germanen" ("Cultic Secret Societies of the Teutons"), Höfler portrayed the belligerent ancestor worship of the Männerbund, centering on an 'ecstatic union' between the living and dead, as a universal Germanic phenomenon with great political significance. For him, the "social demonic" of the Männerbund formed the basis of "unmeasurable socio-political energies"78 that supposedly survived in the all-important political institutions of the Germanic world up until the present day. The Männerbund was thus to be understood as the true carrier of sovereignty and of the forces forming the state. ${ }^{79}$

It was obvious to his contemporaries that using Höfler's theories of continuity, along with his portrayal of dedicated ecstatic and secret warrior bands as being the basis of the Germanic state, could serve as a means of historical legitimization for Männerbund formations within National Socialism, such as the paramilitary $s A$ (Sturmabteilung), and the $s s$ in particular. ${ }^{80}$ Other National Socialists, such as the philosopher Alfred Bäumler, followed this line as well, declaring the Männerbünde as the basis of the state, while emphasizing their ability to defeat the chaos of a bourgeois, urban, feminized way of life. ${ }^{81}$

77 For a more systematic discussion of Weiser's and Höfler's methodology and theories of continuity see Chapter 8 .

78 Otto Höfler, Kultische Geheimbünde der Germanen (Frankfurt a.M.: Diesterweg, 1934), 323, cf. VIII-IX: "Quelle unermeßlicher sozial-staatlicher Energien."

79 Helmut Birkhan, "Otto Höfler. Nachruf," Almanach der Österreichischen Akademie der Wissenschaften 138 (1988), 390.

8 Cf. Stefanie v. Schnurbein, "Geheime kultische Männerbünde bei den Germanen. Eine Theorie im Spannungsfeld zwischen Wissenschaft und Ideologie," in Männerbande Männerbünde. Zur Rolle des Mannes im Kulturvergleich, ed. Gisela Völger and Karin v. Welck (Cologne: Rautenstrauch-Joest Museum, 1990); See, Barbar Germane Arier, 319344. It is fairly undisputed that Höfler's membership in a precursor of the Austrian $S A$ as a 21 year old and his early enthusiasm for National Socialism contributed to his fascination with military warrior associations (cf. Birkhan, "Otto Höfler. Nachruf," 401), and that his theories contain projections of his experiences and political convictions onto ancient ecstatic cults of male bonding, sacrifice, and union with the dead in the Germanic past, cf. Schnurbein, "Geheime kultische Männerbünde bei den Germanen"; See, Barbar Germane Arier.

81 Alfred Bäumler, Männerbund und Wissenschaft (Berlin: Junker und Dünnhaupt, 1934), $3^{2-37 .}$ 
While Hans Blüher's ideas gained influence in parts of the German(ic) Faith Movement, Höfler's and Bäumler's theories were productive in the realm of politics and political philosophy, but less so in religious contexts. As was the case for all Männerbund ideologues, Höfler's approach was clearly antifeminist. He saw female witch cults, with their "cynical dinginess" and "licentious excess," ${ }^{82}$ as one of the main enemies of the firmly structured Männerbund. At the same time, he directed his theories against the blood-and-soil-based, family-oriented, ultimately bourgeois view of Germanic society, which Kummer, Hans F.K. Günther, and other race theorists favored. ${ }^{83}$

With respect to the post-war reception of the Männerbund, we can identify a line from the international conservative-revolutionary and fascist militant ideologies (as developed by Hans Blüher and later taken up by fascist traditionalist Julius Evola) through to present-day political and intellectual right-wing ideologies. ${ }^{84}$ However, Männerbund theories had limited direct impact on modern Asatru. ${ }^{85}$ In order to explain the function of images of male warriors in wider Asatru circles, we have to consider another tradition in which such images feature.

As was the case with 'Germanic' theories of matriarchy and second-wave feminism, the ground for a renewed reception of Männerbund concepts in modern Asatru was laid through the re-contextualization of such gender ideologies in a contemporary movement known as the international mythopoetic men's movement, which emerged in the 1980 s around Robert Bly, a popular poet, translator, performer, leader of men's workshops, and author of the popular book Iron John: A Book About Men. ${ }^{86}$ The men's movement was driven by a

82 Höfler, Kultische Geheimbünde der Germanen, 277: "zynische Schmutzigkeit" - "zügellose Ausschweifung."

83 See in particular the long footnote on Bernhard Kummer, Midgards Untergang. Germanischer Kult und Glaube in den letzten heidnischen Jahrhunderten (Leipzig: Adolf Klein, 1935) in Höfler, Kultische Geheimbünde der Germanen, 336-338.

84 It has lived on in traditional right-wing circles, such as the radical wing of German fraternities, the Burschenschaften, in militant right-wing extremist youth organizations, such as the Wiking Jugend in Germany, as well as in the intellectual New Right. One example, among many, is a book by Karlheinz Weißmann, Männerbund (Schnellroda: Edition Antaios, 2004), who uses Höfler's and Eliade's theories to advocate the necessity of such all-male associations in order to secure a natural, healthy gender order.

85 The links between Asatru groups and Männerbund theories include strongly ethnicist, male-oriented groups such as Hefjendur in Denmark, the now-defunct Allgermanic Heathen Front, and others that promote the neo-right ideas of male heroism.

86 Robert Bly, Iron John. A Book About Men (Vintage Books: New York, 1992 [1990]). Bly's workshops had a strong appeal for many spiritually interested men, who soon published 
similar ambiguity as the pre-World War I Männerbund ideology, as well as the thoughts of a young Hans Blüher. ${ }^{87}$ It rejected both a stifled authoritarian patriarchy and the allegedly overwhelming influence of feminism, considering them to be two of the forces enervating and stifling masculine initiative in modern Western societies. Moreover, it called for a rediscovery of male bonding and traditional masculine values as a remedy for these issues. ${ }^{88}$ The fact that this lack of male strength was attributed to a lack of access to myth and ritual in modernity is important for tracing ideas of the Männerbund in contemporary contexts. ${ }^{89}$ The proper path to a reconnection with "deep and instinctual masculine energies" 90 could be found through initiation rituals. These rituals were grounded in the ethnological tradition Schurtz had introduced; more specifically, the rite through which boys separated from mother and family in order to become accepted as proper men.

Affinities to pre-war Männerbund ideas can also be found in the emphasis on the archetype of the warrior" ${ }^{91}$ the archaic embodiment of "greatness" and "proper aggressiveness"92 - as well as the significance assigned to brotherhoods. ${ }^{93}$ Ecstatic cults, and drumming in particular, play a central role in the mythopoetic men's movement. The integration of the individual man into a larger community and the connection with the power of "the ancestors" 94 or archetypes play a similarly important role as in Höfler's work. Keeping in line

their own books and started their own workshops. See for example Wayne Liebman, Tending the Fire. The Ritual Men's Group (St. Paul, MN: Ally Press, 1991); Michael Meade, Men and the Water of Life. Initiation and the Tempering of Men (New York: Harper San Francisco, 1993).

87 However, it was lacking Blüher's sexual radicalism and instead emphasized the heterosexual union as the natural, mature object choice, resembling Schurtz' and Höfler's ideas in this respect.

88 Bly, Iron John, 2 f. See also Schnurbein, "Kräfte der Erde - Kräfte des Blutes," 259.

89 Cf. Liebman, Tending the Fire, 6. Just as the feminist goddess movement, mytho-poetic men employed a model of archetypes as conceptualized by Carl Gustav Jung, as well as his most famous post-war adept, James Hillman, in order to explain the mythic structures on which the re-connection with archetypal 'natural' masculinities were to be based.

Robert Moore and Douglas Gillette, King, Warrior, Magician, Lover. Rediscovering the Archetypes of the Mature Masculine (New York: Harper San Francisco, 1991), XVIII.

"The warrior" is one of the four "archetypes of the mature masculine," which Jungian psychoanalyst Robert Moore and his co-author Douglas Gillette identify in their popular book, which has appeared in several new editions since its first publication in 1991. Cf. ibid.

92 Ibid., 26 and 80.

93 Cf. for example Meade, Men and the Water of Life, 310.

94 Ibid., 377. 
with earlier propagators of the Männerbund, the figure of the leader has a central function in men's groups, as does the ability for "meaningful submission." 95 Robert Moore and Douglas Gillette associate the ability to be subordinate, which characterizes the good (spiritual) warrior, with his ability to create "new civilizations":

He lives not to gratify his personal needs and wishes or his physical appetites but to hone himself into an efficient spiritual machine, trained to bear the unbearable in the service of the transpersonal goal. [...] And in the very act of destroying, often the Warrior energy is building new civilizations, new commercial, artistic, and spiritual ventures for humankind, new relationships. ${ }^{96}$

The idea that the "social demonic" of the Männerbund constitutes a historical continuity recurs in Wayne Liebman's accounts of "ritual men's group[s]." He writes: "I believe, that even as the old structures die, the psychic energies behind them remain. [...] They live on to find new forms in which to embody themselves."97

The parallels between these mythopoetic ideas about men and German concepts of the Männerbund from the early 2oth century are quite striking. However, the former are not influenced directly by Blüher's or Höfler's ideas. Höfler's work in particular influenced two scholars of Indo-European myth and religion post-1945, George Dumézil and Mircea Eliade. ${ }^{98}$ It was they and their students and followers, as well as students of C.G. Jung, who reintroduced concepts of the Männerbund into the Anglo-American context after 1945. Dumézil's concept of the warrior function, which is based on Höfler's

$95 \quad$ Ibid., 328.

$96 \quad$ Moore and Gillette, King, Warrior, Magician, Lover, 85 and 86.

97 Liebman, Tending the Fire, 41.

98 For a critical discussion of these scholars and Indo-European Studies in general see Chapter 8. My own claim in a previous publication, that scholarship on the Männerbund subsided in post-war years, cannot be upheld, as the works by Hans-Peter Hasenfratz, "Der indo-germanische Männerbund," Zeitschrift für Religions- und Geistesgeschichte 34 (1982); Joseph Harris, "Love and Death in the Männerbund. An Essay with Special Reference to the Bjarkamál and The Battle of Maldon," in Heroic Poetry in the Anglo-Saxon Period. Studies in Honor of Jess B. Bessinger, Jr, ed. Helen Damico and John Leyerle, Studies in Medieval Culture (Kalamazoo, MI: Medieval Institute Publications, Western Michigan University, 1993); and Wilhelm Heizmann, "Germanische Männerbünde," in Geregeltes Ungestüm. Bruderschaften und Jugendbünde bei indogermanischen Völkern, ed. Rahul Peter Das and Gerhard Meiser (Dresden: Hempen, 2002) show. 
descriptions, surfaces in various writings in this context, for example in Robert Bly's Iron John:

If Dumézil is right, one-third of the visions the Indo-European race has ever had in the near or far past amount to visions from the head of the warrior. We could say that a third of each person's brain is a warrior brain; a third of the instincts carried by our DNA relate to warrior behavior $[\ldots]^{99}$

Just as feminist spirituality grounded their conception of gender in the biology of the female body, and their spirituality in the Old European "race," mythopoetic men drew upon Indo-European (formerly Aryan) ideology, as well as an essentialist reading of the male body's biology, in order to re-establish a social order based on an allegedly ancient and natural gender binary. Support for such tendencies, which naturalize belligerent male bonding as a universal characteristic of masculinity and reject the idea that both masculinity and femininity and the ideals surrounding them are constantly constructed and re-constructed in shifting social and historical contexts, is found in sociobiological theory. In Men in Groups (first edition 1969) as well as numerous articles, Lionel Tiger traced the dynamics of male bonding, which allegedly "characterizes human groups as varied as the Vatican Council, the New York Yankees, the Elks, the Masons, and the secret societies of Sierra Leone and Kenya" ${ }^{100}$ back to human evolutionary history and humanity's origin in hunter and gatherer societies. ${ }^{101}$

Considering the broad popular success of Tiger's work and the impact on the mythopoetic men's and other gender-based movements in Western societies, it is unsurprising that theories surrounding the Männerbund were employed in academic discourse as well. ${ }^{102}$ It is also no coincidence that the

99 Bly, Iron John, 150. Interestingly enough, Bly here draws upon a racial and genetic paradigm Dumézil himself rejected, emphasizing social dynamics instead. Dumézil's followers in the New Right, however, often overlooked this abstinence from biologist thought.

100 Lionel Tiger, Men in Groups (New York: Random House, 1969).

101 Ibid. Tiger's book has had a remarkable impact on sociobiological theories of gender and has been published in several new editions, the latest of which appeared in 2007.

102 A case in point is the extensive catalogue which the ethnological Rautenstrauch Joest museum in Cologne published in connection with an exhibition. Both catalogue and exhibition offered a critical approach to the universality of male dominance, which much in the same way as Tiger claimed - was supposedly based on the influence of Männerbünde, and which affirmed the universality of the phenomenon while criticizing it as the singular cause for male dominance. Gisela Völger and Karin v. Welck, eds., 
most carefully argued and critical investigation, in terms of its sources, into the dynamics of Männerbund in Old Norse literature, carried out by Joseph Harris, drew upon Tiger's theses as a justification for the "timeless psychological context"103 of male associations. The socio-biological approach allowed him to find an alternative explanation for the long-term continuity of, as well as the changes in, the dynamics of male bonding.

Mainstream ideas about naturalized traditional masculinities such as these form an inconspicuous ideological ground, distanced from the militant Männerbund ideologies of the political right, on which warrior and Viking masculinities can be developed. While the right-wing reception of Männerbund theories continues to focus on the importance of Männerbünde for state formation and politics, ${ }^{104}$ Asatruers - to the extent that they rely on these theories - tend to emphasize the importance of a mythically grounded, archetypical masculinity of 'the warrior,' from which modern man may draw strength and a sense of belonging. If the Bund is mentioned, it is in the sense of an initiatory association responsible for the guiding of boys into a proper masculinity. A case in point is the German Eldaring member Alex Jahnke's call for the creation of "new Bünde and the revitalization of rites of passage as a central task for the future of Paganism."105 This call reverberates with Our Troth's suggestions on "Man-Making," which refer extensively to Höfler's theories about the 'Wild Hunt' as a remnant of Männerbund activities, and recommends them as sources of inspiration for the appropriate rites of initiation. ${ }^{106}$

Contemporary aesthetic and academic manifestations foster this interpretation of the Männerbund. As we shall see in Chapter 9, metal and neofolk music scenes have embraced Höfler and other German and Austrian folklorists' readings of the Wild Hunt and its association with the Männerbund as a symbol for its aesthetics. ${ }^{107}$ In her recent dissertation, The One-eyed God: Odin

Männerbande - Männerbünde. Zur Rolle des Mannes im Kulturvergleich, 2 vols. (Cologne: Rautenstrauch-Joest Museum für Völkerkunde, 1990).

103 Harris, "Love and Death in the Männerbund," 78.

104 Cf. Weißmann, Männerbund.

105 Alex Jahnke, "Zieh mit den Wölfen. Krieger in der Vergangenheit und Gegenwart," Herdfeuer. Die Zeitschrift des Eldaring e.V. 7, no. 26 (2009), 14. "Hier neue Bünde zu schaffen und Übergangsriten wieder zu beleben, sehe ich als eines der zentralen Themen des Heidentums in der Zukunft."

106 Gundarsson, Our Troth, vol. II, 247-257.

107 Cf. Florian Heesch, “Die Wilde Jagd als Identitätskonstruktion im Black Metal," in Eddische Götter und Helden. Milieus und Medien ihrer Rezeption. Eddic Gods and Heroes. The Milieux and Media of Their Reception, ed. Katja Schulz (Heidelberg: Winter, 2011). 
and the (Indo-) Germanic Männerbünde (2000), ${ }^{108}$ the German translation of which was done by a German Asatruer and published in the Neopagan publishing house Arun in 2007, Kris Kershaw follows Höfler's argument closely, uncritically expanding it to encompass other Indo-European sources. In this way, she offers the first generally accessible account of Höfler's theses in English. In Asatru contexts, the book has been hailed as a long-desired academic justification of Höfler's theories, which were already established via the popular music scene, but lacked the academic credentials that are so important for a-racist Asatruers. ${ }^{109}$

These are the first indicators of a religious reception of Höfler's Männerbund thesis in Germanic Neopagan contexts. However, it should be noted that the notion of a binding, lifelong (secret) association of men is only very rarely mentioned. While the Danish ethnicist Blotgroup Hefjendur's selfconceptualization as a "brotherhood"110 is an exception, generally speaking, the aspects pertaining to the 'spiritual warrior' and to male initiation play a more central role in Asatru. What is neglected in this mode of reception is the original context in which Höfler's theories originated and which formed their image of masculinity, namely, the violent post-ww I German rhetoric and practice of war and 'bloody revenge' of the 'horde of the dead' and their association with extreme right-wing politics. ${ }^{111}$

The tension between this foundational context and recent attempts to distance modern Asatru from its traditional focus on an exaggerated cult of war and the image of the warrior is rarely addressed directly, but can be gleaned from the reactions of some of my interview partners, who have been at pains to reassure me that the enthusiasm for Höfler's and Kershaw's theories are not related to images of gender, but rather to their methodology, which draws upon Indo-European continuities. ${ }^{112}$ This claim is supported by the fact that there are a-racist Asatruers, especially in the USA and Great Britain, who have

108 Kris Kershaw, The One-eyed God. Odin and the (Indo-) Germanic Männerbünde, Journal of Indo-European Studies Monograph (Washington: Institute for the Study of Man, 2000), German translation: Der einäugige Gott. Odin und die indogermanischen Männerbünde, trans. Baal Müller (Engerda: Arun, 2007).

109 For details of this book, its publishing contexts, and methodological, as well as ideological problems around it, see Chapter 8.

110 Cf. http://www.hefjendur.dk/hefjendurs-profil, last accessed August 25, 2014.

111 Richard Faber, 'Wir sind Eines.'Über politisch-religiöse Ganzheitsvorstellungen europäischer Faschismen (Würzburg: Königshausen \& Neumann, 2005), $126 \mathrm{f}$.

112 Cf. Correspondence with Kurt Oertel (Eldaring). The problems of this methodological approach are discussed in Chapter 8. 
used the practice of seid as a means of reevaluating conventional models of masculinity and rejecting their focus on violence. ${ }^{113} \mathrm{Bil}$, one of the Heathen seid practitioners interviewed by Jenny Blain and Robert Wallis, emphasizes that the practice of seid has brought him to embrace a less normative masculinity, to his disavowal of "too much of a 'macho attitude," and towards an "eccentricity" that leads "folks often [to] wonder, now, if I am homosexual or not."114 At the same time, he emphasizes his heterosexuality by rejecting the notion that alternative masculinity is automatically associated with homosexuality, which is strongly stigmatized in at least some Asatru contexts. Annette Høst, a Danish seid practitioner and teacher of shamanism, ${ }^{115}$ makes a similar argument when she points to the ecstatic moments, the loss of control, and the powerful erotic energies which are set free in the practice of seid, which for her are unrelated to gender. She remarks that 'this was what a 'real man' in the Viking society could not deal with socially, but that does not really need to concern us at all today."116

\section{Queering Asatru? The Question of Sexuality}

Such defensive statements point to the fact that seid is indeed associated with the contested site of homosexuality. In spite of Høst's comment that rejections of seid do not need to concern 'us' today, the alleged connections between seid, femininity, and sexually charged magic have led to the idea that seid is not a respectable activity for men. This causes some Asatruers to accuse male practitioners of seid of being ergi (perverted). In medieval Iceland, the terms ergi, ragr or argr denoted an insult so severe that those who used them against another man were legally punished by outlawry. The exact meanings of these insults are hard to determine, but indications point to their gendered and possibly sexualized nature, ranging from generally 'unmanly' and cowardly behavior to the specific insult referring to sexual relations between men, or even

113 Cf. Jenny Blain and Robert J. Wallis, "The 'Ergi' Seidman: Contestations of Gender, Shamanism and Sexuality in Northern Religion Past and Present," Journal of Contemporary Religion 15 , no. 3 (2000).

114 Quote from ibid., 404.

115 Cf. Annette Høst and Karen Kelly, "Keep it Close to Nature. Karen Kelly Interviews Annette Høst on Seiðr, the Old Norse Way of Shamanic Magic," Spirit Talk 9 (1999). Annette Høst founded the Scandinavian Center for Shamanic Studies together with Jonathan Horowitz.

116 Ibid. 
more specifically, the notion of one man being penetrated by another ${ }^{117}$ Some Asatruers use the debasement connected with ergi as proof of the fundamental rejection of (male) homosexuality in Germanic societies. They find further justification for this attitude in Chapter 12 of Tacitus' "Germania", which refers to bog bodies as "corpores infames." This somewhat obscure passage has been read as referring to "sexual acts against nature," and has thus been employed as "proof" of the Germanic rejection and severe punishment of homosexuality by Heinrich Himmler and other National Socialists. ${ }^{118}$

In the wake of these homophobic theories, groups such as the ethnicist Odinic Rite consider homosexuality to be an unnatural "malady," which must be contained in order not to spread and 'infect' the community.119 They despise "the hags of "women's lib" [...] and all the anti-life forces of homosexuality and the touters of abortion" as "part of Loki's Brood." 20 Theodist Garman Lord similarly deplores the "homosexualisation of modern American society, which turns normal people into misfits," and laments gays having 'taken over' Wicca. ${ }^{121}$ Interviews with other Scandinavian and German groups, as well as a search of online forums, confirm that some Asatruers continue to consider homosexuality to be an 'unnatural' or even 'sinful' activity that cannot be reconciled with Heathenism's understanding of itself as a religion of nature (and thus natural reproduction) with a set of 'natural ethics.' This supports the observation that gender relations and reproduction within large parts of Asatru remain dependent on a traditional model based on the nuclear family, with an equally traditional division of labor and tasks.

117 The concept and its sexual and gendered connotations is most comprehensively discussed in Folke Ström, Nið, Ergi and Old Norse Moral Attitudes (London: Viking Society for Northern Research 1973), Preben Meulengracht Sørensen, The Unmanly Man. Concepts of Sexual Defamation in Early Northern Society (Odense: Odense University Press, 1983), Carol J. Clover, "Regardless of Sex. Men, Women, and Power in Early Northern Europe," Speculum 68 (1993). Cf. also the discussion by anthropologist and Asatruer Jenny Blain, Nine Worlds of Seid-Magic. Ecstasy and neo-Shamanism in North European Paganism, 18, $115 \mathrm{f}$.

118 Cf. Karin Sanders, Bodies in the Bog and the Archaeological Imagination (Chicago/London: University of Chicago Press, 2009), 61-65.

119 WulfstanOR, "Odinic Values in Family Life \& Personal Relationships," The Odinic Rite, http://www.odinic-rite.org/main/odinic-values-in-family-life-personal-relationships/, last accessed May 29, 2015.

120 The Circle of Ostara, "Loki," The Odinic Rite, http://www.odinic-rite.org/main/loki/, last accessed November 29, 2011.

121 Lord, The Way of the Heathen, 85f, 95 . 
At the same time, Germanic Neopagans past and present generally agree that Pagan attitudes toward sexuality are freer and "more natural" than those of Christianity and other monotheistic or "oriental" religions and cultures - an assessment which they share with other Neopagans, especially Wicca and Neoshamans. However, as we have seen in the previous chapter, the concrete meaning of 'natural' varies considerably. Attitudes toward the nature of sexuality within Germanic Neopaganism have always oscillated between an orientation toward family values and traditional morals, and the experiments with sexual magic characteristic of occult orders. The German Faith Movement saw Germanic sexual morals as characterized by a "natural" distance from "lasciviousness" and "artificial eroticism," setting them against the "lecherousness" of Romance morals. ${ }^{122}$ The predominance of such attitudes left little room for deviant visions of sexual order, such as those of Willibald Hentschel and Ernst and Margart Hunkel, who advocated polygamy in the service of effective racial breeding. ${ }^{123}$

Ariosophist Guido List's esoteric system, which consists of a fundamental polarity which permeates the cosmos, and is the basis for a successful expansion of the Ario-Germanic race, has implicit sexual connotations. His breeding fantasies teem with sexual imagery. List's ideas are in part based on the work of Max Ferdinand Sebaldt von Werth (1859-1916). Combining ideas of nudism, occultism, and racial breeding, von Werth, the chair of a theosophical lodge and member of a Druid order, developed a veritable sexual religion of Aryan superiority in which "the distinct Nordic sense of polarity" and the "trinity of the highest powers" played a central role. ${ }^{124}$ It is thus logical that Hunkel included more Ariosophic elements into the ideology of the Order of the Nordungen, which he founded later in his life. However, to my knowledge, there are no indications that Ariosophist circles practiced sex magic, or were involved in tantric activities to a

122 Cf. Zernack, “'Germanin im Hauskleid.”

123 Hunkel was excluded from the Deutscher Orden and Deutschgläubige Gemeinschaft on the grounds of his promoting the "Mittgard polygamy." Cf. Chapters 1 and 6. Cf. also Breuer, Die Völkischen in Deutschland, 104.

124 Ellic Howe and Helmut Möller, Merlin Peregrinus. Vom Untergrund des Abendlandes (Würzburg: Königshausen \& Neumann, 1986), 151; Maximilian Ferdinand Sebaldt von Werth, 'Wanidis.' Der Triumph des Wahns III: D.I.s. Die arische 'Sexualreligion' als VolksVeredelung in Zeugen, Leben und Sterben. Mit einem Anhang über Menschenzüchtung von Carl du Prel (Leipzig: Friedrich, 1897), 31: "ausgeprägter nordischer Sinn für Polarität" "Dreiheit höchster Gewalten.” Cf. also Bernd Wedemeyer-Kolwe, 'Der neue Mensch.' Körperkultur im Kaiserreiche und in der Weimarer Republik (Würzburg: Königshausen \& Neumann, 2004), 200. 
similar extent as contemporary occultists, adherents of Aleister Crowley and Anglo-German occultist Theodor Reuss, ${ }^{125}$ or the founders of Wicca, with their rituals of fertility steeped in sexual symbolism. ${ }^{126}$

The association between a general notion of Neopaganism and sexual magic is one reason why in recent years many members of sexual minorities, be they gay or lesbian, sado-masochistic or fetishist, have sought their spiritual home in Neopagan circles, and that the proximity between the queer- and BDSM ${ }^{127}$ scenes and Neopaganism is relatively close. ${ }^{128}$ Their association with sexual magic, Wicca, and neo-shamanism makes contemporary Asatruers who include sexuality in any form into their spiritual practices targets of suspicion within the community. The ensuing tensions around these issues are not easily attributed to any of the political camps within Asatru. As is the case with feminist spirituality, we can find overlaps between sexual libertarianism and racist or ethnicist ideologies. Stephen Flowers, alias Edred Thorsson, is an example of this. Although he shares the Odinic Rite's ethnicist outlook and embraces views of the New Right, his involvement with ritual sado-masochism and his foundation of the Order of the Triskelion in the 1980 s based on Pauline Réage's The Story of $O$, the classic novel on sado-masochism, led to his exclusion from the Odinic Rite $(O R)$ and to a minor scandal within the Heathen scene. ${ }^{129}$ A-racist Asatruers are somewhat divided on the issue as well. The majority claim to be perfectly accepting of gays in their own ranks and avoid taking a strong stance on homosexuality by considering sexual preference to be an individuals' personal decision and thus not the community's affair, and therefore an issue that has nothing to do with religion. ${ }^{130}$ Where legally possible,

125 Howe and Möller, Merlin Peregrinus, 136-170.

126 Cf Hutton, The Triumph of the Moon, 231-236.

127 The acronym stands for Bondage, Dominance, Submission, Sadism, and Masochism.

128 To mention just one prominent example: The prolific writer and sex educator, Pat(rick) Califia, who has written a great number of works on queer sado-masochism, radical sexual politics, and trans-gender issues, promotes an "indigenous paganism" as the way for white people who strive to avoid a cultural imperialism." (Pat Califia, Public Sex. The culture of radical sex (Pittsburgh: Cleis Press, 1994), 240). Califia is a member and priest of the Fellowship of the Spiral Path (Cf. Michael Manning, Inamorata. The Erotic Art of Michael Manning (San Francisco: Last Gasp, 2005): Information on contributors), which was founded by Marion Zimmer Bradley and is now headed by Diana Paxson and which Paxson.

129 Cf. Kaplan, Radical Religion in America, 26f; Edred, History of the Rune-Gild, III (The Reawakening of the Gild 1980-2005), 90-93.

130 Members of the German VfgH and Eldaring as well as the American Troth and all Scandinavian groups have professed this position. 
Scandinavian groups have embraced same sex marriage. In fact, in Iceland, the Ásatrúarfélagið was the first religious community to officially wed same sex couples. In these groups, any dissent usually revolves around the fact that marriage and procreation are supposed to be closely linked. In most groups, the issue is resolved by letting individual godis and gydjas decide which rites they want to perform. Nevertheless, openly homosexual Asatruers remain a small minority. To my knowledge, the Swedish a-racist Samfundet Forn Sed is the only European group to count a very small homosexual/bisexual/transsexual or queer association among its blotgroups. ${ }^{131}$

The most radical practitioners, who work explicitly with the sexual nature of seid, ergi, or Northern shamanism, often do not identify explicitly as Heathen or Asatru, and do not feel connected to the Asatru community, but rather find it important to follow a "Northern way" within a more general Neopagan framework. Among them is Raven Kaldera, a queer "intersexed" and "transgendered" "author, shaman, and activist," who combines the spiritual ways of the "Northern ancestors" with the practices of polyamory and ritual sado-masochism. ${ }^{132}$

Other queer seid practitioners, including Jenny Blain and Robert Wallis, combine their anti-homophobic activities with a strong stance against racist or ethnicist tendencies within Asatru in their discussion of seid. Others, however, connect their support for sexual freedom and tolerance with the type of ethnicist and anti-monotheist argument discussed in Chapter 5 , and see sexual libertarianism as an integral part of Germanic culture. For example, Stephen Flowers/Edred Thorsson and his wife Crystal Dawn conceptualize sadomasochism as being a part of "our culture":

Sexuality in all its forms, and most especially in this form, was suppressed (or sublimated) by the teachings of the medieval church, or pathologized by 19th century "professors." During the 2oth century in European culture, however, the sacred power of sexuality is being rediscovered. The

131 Bilröst was founded in 2009 after "homo-Heathens" walked in the Stockholm Gay Pride Parade in 2008 with a statue of the god Freyr, as a reaction to anti-gay tendencies within Asatru, and with the hope of contributing to breaking the association between Asatru and racist and violent groups. Cf. Urban Johansson, "Innkalling til Pride," Mimers Källa 21 (2009), Håkan Lindh, "En нвт-hedning taler," Mimers Källa 21 (2009). As the example shows, "Homo-Heathens" orient their practices not only around seid, but also around the fertility god Freyr, whose Uppsala priests, according to Saxo Grammaticus, cross-dressed in ritual.

132 Cf. http://ravenkaldera.org/rumors.html, last accessed August 25, 2014. 
apparently "new" interest in Sado-Masochistic sexuality is really just a renewal of something very ancient in our culture. ${ }^{133}$

Carl Johan Rehbinder, the chair of the Swedish SAS (now Samfundet Forn Sed) from 2000 to 2003 and teacher of tantric workshops in which he combines Nordic and other cultural elements, ${ }^{134}$ stands for libertarian politics, with a critical stance toward Islam as well as Christianity. ${ }^{135}$ Rehbinder has collaborated closely with sex educator Pia Struck and her Orgasm Academy in Denmark. ${ }^{136}$ Struck has been a long-term member of Harreskoven Blotgilde, where she serves as a gydja, and has been partnered with Grølheim, co-founder of Harreskoven Blotgilde and Forn Siðr, and editor of the now-defunct journal, Valravn. Grølheim has shown active interest in issues of gender transgression and queerness, and has published an article in Valravn on the significance of ergi, gender, and homosexuality in Old Germanic and antique societies. ${ }^{137} \mathrm{He}$ has also publicly championed sexual and phallic aspects of the god Freyr at a mysticism fair (mytikmesse) in Denmark in 2000. ${ }^{138}$

The public activities of Struck and Rehbinder, which reach far beyond Asatru, point to the fact that their attitudes toward sexuality and ethnicity are compatible with at least parts of mainstream queer theory and activism. From a critical perspective, their standpoint can be compared to what has been termed "homonationalism" in recent years. "Homonationalism" describes a sexual politics in which

claims to new or radical sexual freedoms are appropriated precisely by that point of view - usually enunciated from within state power - that would try to define Europe and the sphere of modernity as the privileged site where sexual radicalism can and does take place. Often, but not

133 Crystal Dawn and Stephen Flowers, Carnal Alchemy. A Sado-Magical Exploration of Pleasure, Pain and Self-Transformation (Smithville, TX: Runa-Raven Press, 1995), $11 \mathrm{f}$.

134 Ravn, "Interview med Carl Johan Rehbinder, en svensk hedning," 8. Cf. also Rehbinder's webpage http://www.cirkuseros.nu/sidor/om.html, last accessed August 25, 2014.

135 See, for example, his comments on Islam on http://ligator.wordpress.com/2010/08/28/ fraga-till-sverigedemokraterna-om-islam-ar-som-nazismen-vad-gor-ni-med-muslimerna -da, last accessed Aug 25, 2014. Rehbinder has otherwise been active in the small party Piratparti, as well as in the new party of the Liberal Democrats. (Cf. his blog http://tantrikblog.wordpress.com, last accessed August 25, 2014).

136 http://www.orgasmeakademiet.dk, last accessed August 25, 2014.

137 Grølheim, “Køn, Sex og Ergi," Valravn. Hedensk tidskrift om samfund og kultur 24 (2008).

138 Photos of his presentation can be found on his facebook page at https://www.facebook .com/Grolheim/photos, last accessed August 25, 2014. 
always, the further claim is made that such a privileged site of radical freedom must be protected against the putative orthodoxies associated with new immigrant communities. ${ }^{139}$

In other words, Western societies' inclusion of (some) 'proper' homosexual subjects in the realm of the nation is taken as proof of the progressive and tolerant nature of these 'modern' societies and is set against allegedly illiberal, homophobic Islamic or Asian traditions. A certain form of secularism indicated by sexual freedom is thus turned into an absolute value that characterizes 'good' societies, while at the same time foreclosing religious tolerance or the negotiation of differences in pluralistic societies. ${ }^{140}$

Asatruers who embrace such ideals combine them with ethnicist positions, turning the praiseworthy tolerance of 'modernity' into a timeless marker of the 'Germanic' or 'Nordic' cultural tradition or essence. Instead of representing state power, they give the homonationalist argument an ethnicist twist by projecting the notion of modern libertarianism onto the preChristian past, and by configuring its current emergence as a recovery of an ethnic or cultural essence destroyed by Christianity and currently threatened by monotheistic Islam. We could interpret this as an ethnic essentializing of homonationalism, secured through a spiritualized ethnic identity rooted in a deep past.

This kind of 'homo-ethnicism' is not the sole preserve of Asatruers, but is shared by academic theories which utilize aspects of queer theory for innovative interpretations of Norse mythology and society. In turn, these are employed by Asatruers to support their beliefs. A case in point is Norwegian archeologist Brit Solli's book about the otherness of Viking society and the queer character of its main god, Odin, published in 2002 under the title "Seid - Myter, sjamanisme og kjønn i vikingenes tid" (Seid - myths, shamanism, and gender in the Viking age). Solli sets out to refute once and for all nationalist or National Socialist appropriations of Viking culture. She rejects the notion of cultural or ethnic identity and asserts the shamanistic, sexual, and queer nature of Viking society's most prominent god, Odin. At the same time, she uses theories of otherness derived from queer and postcolonial studies to make an antimonotheistic claim, stating that the Heathen worldview is fundamentally different from any monotheism. Her anti-Islamic agenda is revealed in her attack on Muslims during a passage on the 'deplorable' influence of Christianity on

139 Butler, "Sexual Politics, Torture, and Secular Time," 2.

140 Cf. Puar, Terrorist Assemblages. 
Viking culture, which has absolutely nothing to do with Viking culture's encounters with Arab and Islamic cultures. ${ }^{141}$

Such incidents are examples of Asatru's increasing tendency to align itself with alternative, yet respectable social movements, and of Asatruers' tendencies to adopt ethnicist and cultural essentialist positions within such movements. They point to the important intersection of academic theory with Asatru, which will be discussed in the following chapter.

141 Cf. Brit Solli, Seid. Myter, sjamanisme og kjønn i vikingenes tid (Oslo: Pax, 2002), 76 and 232. 